\title{
Representation of the Articulation between Spheres of Life
}

\author{
Hanen Khanchel $^{1}$ \& Karim Ben Kahla ${ }^{2}$ \\ ${ }^{1}$ Institute of Advanced Business Studies, Carthage, Tunisia \\ ${ }^{2}$ High Business School, Campus of Manouba \\ Correspondence: Hanen Khanchel, Institute of Advanced Business Studies, Carthage, Tunisia. E-mail: \\ Hanen.Khanchel@gmail.com
}

Received: December 6, 2018

Accepted: June 18, 2019

Online Published: June 20, 2019

doi:10.5430/bmr.v8n2p10

URL: https://doi.org/10.5430/bmr.v8n2p10

\begin{abstract}
Our paper aims to improve the understanding of the articulation between spheres of life among Tunisian managers, by mobilizing a mixed theoretical framework. In this context, we develop a model of representation of spheres of life simultaneously explaining the structural relationships between its different areas. This conceptual model is validated on data collected from the Word Values Survey. However, the model obtained leads to a certain hierarchy of the effects of the spheres of life.
\end{abstract}

Keywords: representation model, structural equations, spheres of life, manager

\section{Introduction}

In a context marked by the intensification of the pace of work, precarious employment, restructuring, urgency and shortened deadlines, human resources are the main resources of the company. It relies more and more on the human factor to strengthen its competitive position and also its durability. The social responsibility of the company is to ensure a healthy environment for its employees who no longer wish to sacrifice their privacy at the expense of their professional career (Colle and Christin, 2008). This is evidenced by the Gallup (2013) survey, which reveals that 95\% of Tunisian employees are not engaged in their job. Similarly, a study by the World Values Survey (2018) suggests that $41 \%$ of Tunisians believe that when women work, this has a negative impact on the balance of the family and especially children. Faced with these findings, companies must more than ever listen to their employees and take into account their difficulties in reconciling the private and professional spheres. Do not neglect the negative effects of work-to-work interference, such as increased turnover, absenteeism, delays, and reduced commitment, to optimize the company's economic and social performance in the workplace. An increasingly competitive world where the human factor is a fundamental lever of the company's performance. By becoming aware of the issue of the articulation of living times for employees and organizations, governments and professionals in developed countries are offering more and more benefits facilitating the reconciliation between private and professional life. These practices encouraging reconciliation between spheres of life were first developed in the United States in the 1970s and 1980s with the introduction of spatio-temporal flexibility measures such as teleworking, the organization of working time, etc. (Tanquerel and Barth, 2012). Or with the introduction of services, advice, financial assistance and infrastructure (extended parental leave, setting up a business-to-business crèche, etc.) (Laquelle, 2013). Other measures also deserve to be mentioned, in particular that of the French government, by introducing the reduction of working hours (RTT), which was intended first and foremost to break the spiral of unemployment but also the objectives of reconciling employment (Tremblay, 2012). Today, a new model of the work-life relationship seems to emerge in these countries. What about the situation in Tunisia? And what perceptions do our Tunisian managers have of the question of the link between working time and non-work time?

As part of this research, we are particularly interested in the category of managers. This is linked to the specificity of their relationship to working time and the blurred nature of the boundaries they establish between work and non-work. In fact, the population of managers is characterized by a relationship with time that is "elastic", qualitative and cyclical (Mongrand 1999, Lefèvre et al., 2000, Bouffartigue and Bocchino 1998, Pochic 2000), but also by a blurred relationship between their areas of life (Guilbert, 2006). Autonomous and responsible for a mission, the manager has the opportunity to decide on the means he will implement and therefore the limit where his work day begins and ends (Lejealle, 2009). Thanks to the development of ICT, today's frameworks are "borderless" (Desmarais, 2006), which 
leads to a complex articulation between different social times (Lenoir , 2014). Managers thus represent the socioprofessional category most concerned by the overflow of professional life in the domestic sphere (Felio, 2004).

The fact that the introduction of high technologies has considerably and durably changed the management and organization of work does not mean that the quality of the relationship to work has been improved. For Rallet and Wolkowiak "the use of ICTs would give more autonomy and responsibility to managers by giving them more freedom in the organization of their work", (Rallet \& Wolkowiak, 2004, cited by Tran, 2014, p. 33). This resulted in an increase in the mental burden of the manager. On the other hand, Eric Brousseau and Alain Rallet (1997) warned in 1997 that ICT could be used to codify, automate and standardize the activities of employees (Brousseau \& Rallet, 1997). The digitalization of work can also be accompanied by the development of a permanent control of the activity, as Dominique Carré and Jacques Vétois (2016, p.2-3) underline: "the computer will (...) very quickly handle personal information concerning natural persons, their knowledge, their behavior, their mode of operation ".

Alain Roquejoffre (2017, p.3) notes that "the hopes they raise sometimes lead to a willingness to submit to their requirements and their criteria for configuring the world". Margot Beauchamps (2012, p.11) talks about digital dependence, that is, "a social configuration in which everything is designed for ICT users". For the author, there is a strong incentive to use technologies, including the Internet, to access a vast amount of information.

Marie Benedetto-Meyer and Nicolas Klein (2017, p.10) consider that a digital transformation can only succeed if the company engages in a profound change in its organization. Otherwise, the transformation may be: "source of tension, intensification of work or loss of benchmarks". Digitization has exacerbated the pressure on executives to demonstrate their responsiveness in organizations seeking agility, innovation or ability to overcome obstacles. The study of creativity at work (Amado et al., 2017) is an illustration of this. Subjected to paradoxical injunctions such as "be creative while respecting the organizational culture", managers more than employees find themselves unable to meet the demands of their position. Lucie Davoine and Dominique Méda (2009, p.53) stressed that stress and burnout contributed to a deterioration of the relationship to work.

Other factors may occur. A trend towards individualization of work has been widely emphasized. Digitization favoring work at home has accentuated this phenomenon. If it has also been accompanied by the emergence of new modes of cooperation by opening up new possibilities of instantaneous interactions and permanent contacts, including with a collective (Laulan, 2016), the reduction of direct contacts and atomization working communities have exacerbated the loneliness of executives in the face of increasingly burdensome responsibilities.

Our problematic aims to acquire a better understanding of the modes of articulation between working time and non-work time and to describe how this is revealed among Tunisian managers. We thus seek to better understand the phenomena of interweaving and interference of personal temporalities and professional temporalities and the logic of development of such practices in order to better define and explain these interactions and their consequences for Tunisian managers.

Our research problem can be expressed as follows: How is represented the articulation between the spheres of life among Tunisian managers?

The purpose of this research is thus to shed light on the representation of the articulation between the spheres of life. To do this, we present a conceptual model that simultaneously takes into account the interactions between its different components. At the methodological level we specify a model of structural equations that explains the causal relationships between the different spheres of life among Tunisian managers. Its validation is based on data collected from Word Values Survey (2018), whose dual identity leads them to seek an optimal articulation between spheres of life. This paper is organized in two parts. Firstly, we present the theoretical foundations of the model of representation of the articulation between the spheres of life, then the procedure of its validation. In the second part we discuss the results of the empirical analyzes, before explaining the implications.

\section{The Theoretical Research Framework}

The term articulation between spheres of life was proposed for the first time by Marie-Agnès Barrère-Maurisson in 1992 (Ollier-Malaterre, 2008). The work-to-work relationship allows for both negative and positive effects of the interaction between work and non-work, but also implies that the individual can be active in this interaction (Tessier, 2009). Two spheres are cross-correlated and are in relative autonomy. Each sphere is subject to its own laws; relative, because the common logic of the gendered division of labor assigns their places to men and women in both spheres. This is the concept adopted by several French researchers, particularly in the context of EQUAL European studies (Silvera, 2002, Silvera \& al., 2004, Tremblay, 2008, Del Río Carral, 2009). We then opt for the term " articulation of the spheres of live ". This expression emphasizes the interdependence of the professional and private worlds (Chrétien, 
2005). The concept of "articulation" refers more in its mechanical definition to the idea of an (articulated) system where the different spheres are united in such a way that a change in one of them leads to deformation of the figure formed by the system. It reflects the interweaving of the two spheres without prejudging the result of this interrelationship (Brais, 2000). Chrétien (2005) makes an analogy with the human body: the thigh and the calf operate in opposite directions, but being tied by the knee, this allows the whole leg to move forward one step. The term "articulation" also makes it possible to integrate the notion of "porosity", which implies the development of the different dimensions that manifest themselves between the spheres of life (Del Río Carral, 2009).

To conclude, we propose to present a summary table of St-Onge (Table 1) through which he proposes a synthesis of research that has studied the determinants or effects of work-family conflict. The list presented does not pretend to be exhaustive but allows us to situate the various researches in relation to each other.

Table 1. Synthesis of research that has investigated the determinants of the interaction between work and non-work

\begin{tabular}{l}
$\begin{array}{l}\text { Determinants of } \\
\text { Work-Off-Work } \\
\text { Interaction }\end{array}$ \\
\hline Sex \\
Civil status \\
Age \\
Exhaustion, fatigue \\
Value given to work and \\
family \\
Nombre d'heures de travail \\
Number of working hours
\end{tabular}

\section{The studies}

Chenevier, 1996 ; Crouter, 1984 ; Duxbury et Higgins, 1991 ; Frone et Rice,1987 ; Frone, Russell et Cooper, 1992 ; Gutek, Searle et Kepla, 1991 ; Keith et Schaffer, 1980 ; Lazzari et Tremblay, 2014 ; Tremblay, 2015 ; Scott et al., 2015

Chenevier, 1996 ; Duxbury, Higgins et Lee, 1993 ; Kelly et Voydanoff, 1985 ; Hartmann, 1981 ; Katz et Piotrkwoski, 1983 ; Vinokur, Pierce et Buck, 1999; Tremblay, 2014 ; Tremblay, 2015

Keith et Schafer, 1980 ; Vinokur, Pierce et Buck, 1999 ; Voydanoff, 1988 ; Tremblay, 2015 ; Nohe et al., 2014 ; Lazzari et Tremblay, 2014

Leiter et Durup, 1996 ; Nohe et al., 2014

Carlson et Kacmar, 2000 ; Turliuc et Buligia, 2014

Aryee, 1992 ; Carlson et Kacmar, 2000 ; Gutek, Searle et Kepla, 1991; Katz et Piotrkwoski, 1983 ; Keith et Schafer, 1980 ; Kinnunen et Mauno, 1998 ; Lero et al., 1993 ; Voydanoff, 1988 ; Yang et al., 2000 ; Scott et al., 2015

Aryee, 1992 ; Aryee, Field et Luk, 1999 ; Boles et, Babin, 1996 ; Nature of roles Carlson et Kacmar, 2000 ; Chenevier, 1996 ; Duxbury et Higgins, 1991; (expectations, ambiguity, Frone, Russell et Cooper, 1992 ; Frone, Yardley et Markel, 1997 ; conflict, overload, stress) Kinnunen et Mauno, 1998 ; Parasuraman et Greenhaus, 1992 ; Voydanoff, 1988 ; Scott 2015 ; Kengatharan, 2015

Nature of work Aryee, 1992 ; Boles, Johnston et Hair, 1997 ; Chenevier, 1996 ; (requirements, variety, Duxbury et Higgins, 1991 ; Katz et Piotrkwoski, 1983 ; Kinnunen et complexity, autonomy, Mauno, 1998 ; Leiter et Durup, 1996 ; Pleck, Staines et Lang, 1980 ; personal achievements) Voydanoff, 1988 ; Yang et al., 2000 ; Scott et al., 2015

Commitment or involvement in the work; demands / requests

professional

Nature of work schedules (eg irregularity, inflexibility, part time, shift)
Aryee, 1992 ; Aryee, Field et Luk, 1999 ; Carlson ; Kacmar, 2000 ; Chenevier, 1996 ; Duxbury et Higgins,1991 ; Frone, Russell et Cooper, 1992 ; Frone, Yardley

Markel, 1997 ; Greenhaus et Kopelman, 1981 ; Gutek, Searle et Kepla, 1991; Vinokur, Pierce et Buck, 1999 ; Yang et al., 2000 ; Liang, 2015 ; Scott 2015

Aryee, 1992 ; Chenevier, 1996 ; Higgins, Duxbury et Johnson, 2000 ; Katz et Piotrkwoski, 1983 ; Kinnunen et Mauno, 1998 ; Thomas et Ganster, 1995 ; Voydanoff, 1988 ; Lazzari et Tremblay, 2014 ; Ju et al., 2015 
Job Categories

Support from spouse and family members

Stressors and family conflicts (eg ambiguity of family roles, expectations)

Age of children

Nature of employment of spouse

Number of children

Commitment involvement in the family

Parental burden or overload (number and age of children), requirements and

family demands

Satisfaction with the spouse

Working environment

Values, social culture

Support in the workplace (eg, support from supervisor or colleagues, values, cultures)

Presence of work-family balance practices

Satisfaction with
work-family balance
practices and their use

Impact of ICT
Chenevier, 1996 ; Duxbury, Higgins et Lee, 1993 ; Greenhaus et Kopelman, 1981 ; Kengatharan, 2015

Aryee, 1992 ; Carlson et Perrewé, 1999 ; Carlson et Kacmar, 2000 ; Deneault, 1996 ; Frone, Yardley et Markel, 1997 ; Goff, Mount et Jamison, 1990; Keith et Schafer, 1980 ; Parasuraman et Greenhaus, 1992 ; Tremblay, 2015 ; Liang, 2015

Aryee, Field et Luk, 1999 ; Carlson et Perrewé, 1999 ; Carlson et Kacmar, 2000 ; Duxbury et Higgins, 1991 ; Frone, Russell et Cooper, 1992 ; Leiter et Durup, 1996 ; Parasuraman et Greenhaus, 1992 ; Vinokur, Pierce et Buck, 1999 ; Yang et al., 2000 ; Nohe et al., 2014 ; Jamadin, 2015.

Chenevier, 1996 ; Greenhaus et Kopelman, 1981 ; Katz et Piotrkwoski, 1983 ; Kelly et Voydanoff, 1985 ; Kinnunen et Mauno, 1998 ; Voydanoff, 1988 ; Tremblay, 2015 ; Scott, 2015

Aryee, 1992 ; Chenevier, 1996 ; Duxbury, Higgins et Lee, 1993 ; Greenhaus et Kopelman, 1981 ; Keith et Schafer, 1980 ; Kinnunen et Mauno, 1998 ; Doo Hun Lim et al., 2012 ; Tremblay, 2014

Chenevier, 1996 ; Katz et Piotrkwoski, 1983 ; Keith et Schafer, 1980 ; Kinnunen et Mauno, 1998 ; Voydanoff, 1988 ; Yang et al., 2000 ; Tremblay, 2014 ;

Aryee, 1992 ; Aryee, Field et Luk, 1999 ; Carlson et Kacmar, 2000 ; Chenevier, 1996 ; Duxbury et Higgins, 1991 ; Frone, Russell et Cooper, 1992 ; Frone, Yardley et Markel, 1997 ; Gutek, Searle et Kepla, 1991; Tremblay, 2014

Carlson et Perrewé, 1999 ; Frone, Yardley et Markel, 1997 ; Yang et al., 2000 ; Liang et al., 2015

Leiter et Durup, 1996 ; Doo Hun Lim et al., 2012 ; Liang, 2015

Yang et al., 2000 ; Turliuc et Buligia, 2014 ; Liang, 2015

Allen, 2001 ; Clark, 2001 ; Carlson et Perrewé, 1999 ; Deneault, 1996 ; Frone, Yardley et Markel, 1997 ; Goff, Mount et Jamison, 1990 ; Love, Galinski et Hugues, 1987 ; Parasuraman et Greenhaus, 1992 ; Thomas et Ganster, 1995 ; Alis et al., 2003 ; Perlow et al., 2014

Allen, 2001 ; Bohen et Viveros-Long, 1981 ; Deneault, 1996 ; Friedman, 1990 ; Goff, Mount et Jamison, 1990 ; Perlow et al., 2014 Tremblay, 2015 ; Jamadin, 2015

Goff, Mount et Jamison, 1990, Ju et al., 2015

Amegee, 2002 ; Tremblay, 2008; Othman, 2009 ; Kotecha et al., 2014 ; Félio, 2014

Source: Adapted from St-Onge \& al., 2002

We can conclude from this summary - not exhaustive - of the determinants of the articulation between the spheres of life that there exists a combined set of factors (economic, organizational and personal) of differentiation of the weekly 
working hours which characterizes the "cadre" population (Hervet, 2001). Certainly, it remains difficult, even useless, to measure the weight of each of these factors by linking the relationships between the areas of life established by the managers, because it is their articulation that makes sense for them (Guilbert and Lancry, 2007).

In this context, we develop a model of representation of spheres of life simultaneously explaining the structural relationships between its different areas.

\section{Methodology}

The empirical study is based on the specification of a model of structural equations comprising a measurement model and a structural model: the causal relationships between the joint and its domains of life, and the interactions between the different spheres. The validation phase is performed on database of Word Values Survey (2018) from a sample of Tunisian managers working in various sectors of activity. Similarly, for this sample to encompass a sufficiently broad range of trades, we have systematically sought to question production managers and support function executives. The selection of companies and managers is therefore essentially based on these two criteria.

From a methodological point of view, this conceptualization of the articulation between the spheres of life can be represented by a second order measurement model with two levels of abstraction: the articulation between the domains of life (the superfactor h) and its determinants (factors xi). This is why we adopt the procedure of developing a measurement model recommended in the literature (Jarvis \& al., 2003). Although we privilege this conceptualization of the articulation between the spheres of life, we have also specified a model of measurement in which the domains of life are taken isolation. The objective is to determine which of these two conceptualizations best fit the data through statistical indicators of the estimated structural equation model.

\section{The Measuring Scales}

The process of developing and purifying these items is done in two stages. First, the operational definitions of the different concepts and the often parceled measures proposed in the literature allowed us to generate a set of statements for each scale. The facial validity of these scales was the subject of a semi-directive interview with Tunisian managers. After judging that the validity of the content was satisfactory, we used a database of Word Values Survey (2018) to analyze our sample of Tunisian managers containing the different scales. It is restructured from the conceptual model presented.

Finally, we developed measurement models for each of the theoretical constructs.

Our procedure is based on work on the elaboration of a measure (Jarvis \& al., 2003): the examination of the convergent and discriminant validities of the measurement scales was carried out using exploratory and confirmatory analyzes.

\section{The Structural Model}

- $\quad$ To examine the hypothetical dependence relationships postulated by the general and adjacent hypotheses described initially, we first specified a model of structural equations:

- $\quad$ Model I: Structural Equation Model Without Moderator Variables

$$
\eta \quad=\mathrm{B} \eta+\Gamma \xi+\zeta
$$

- $\quad$ With the following notation: $\eta$ (PSYCHOLOGICAL ARTICULATION, RELATIONAL

ARTICULATION, TEMPORAL ARTICULATION, ARTICULATION BETWEEN SPHERES OF LIVE) and $\xi$ (Private sphere, Cultural variables, Professional sphere, $\zeta$ the error term.

- $\quad$ We have also specified a rival structural model in which the overall performance is segmented, namely:ARTICULATION = f1 PSYCHOLOGICAL ARTICULATION + f2 RELATIONAL ARTICULATION + f3 TEMPORAL ARTICULATION $+\zeta$

- $\quad$ With PSYCHOLOGICAL ARTICULATION = $\alpha \alpha i$ Indpi;

RELATIONAL ARTICULATION $=\Sigma \beta i$ Indri; TEMPORAL ARTICULATION $=\Sigma \gamma i$ Indti; Indp Indr, Indt are respectively the indicators of measurement of the psychological, relational and temporal articulation, (the items of the scales of measures) and the coefficients: $\phi, \alpha, \beta, \gamma$ represent the weight of each of the indicators. To judge the validity of a model, we used the indices of adjustments recommended in the literature (Kline, 2011). Table 2 summarizes the main model I fit indices are satisfactory. It shows that, with respect to the accepted thresholds, Model I cannot be rejected. Moreover, the rival model (equation 2) is rejected relative to the model I. We can therefore argue that a propoed conceptual model combining these different spheres of life has an explanatory power superior to a model dissociating the different spheres of life. 


\section{The Conceptual Model}

The model for measuring the relationship between the spheres of life explains the interactions between the different domains: working life and private life according to the definition used above. Formally, this model in itself is under-identified, and requires other structural relationships to estimate its parameters. In the case of the articulation between the spheres of life, these relate to the modes associated with the different dimensions of articulation between the spheres of life. The articulation of the different variables selected from the qualitative study (Khanchel H., 2016). Nevertheless, our conceptual model differs in several points from the model proposed both in the content of the variables, but also in the articulation of the three components of the analysis. Thus, in our model, the structure factors are control variables and the behavior factors correspond to the modes of articulation between the spheres of life. For the sense of the relations between the different variables, the qualitative study predicts a positive causal relation between the modes of articulation between the spheres of life. In view of these different contributions, our conceptual model for measuring is shown in this part. It shows, the causal links expected from the literature admit positive and negative relationships. The direction of structural relationships expected between the variables of the conceptual model are argued in the presentation of the content of the constructs and their measurements.

\section{Delimitation of the Contents of the Constructs}

This essential phase of delimiting the contents of the different constructs of the conceptual model of representation of the articulation between spheres of life rests on both the literature and the qualitative study (Khanchel, 2016).

The psychological articulation: It is the psychological and emotional load in relation to the personality generated by one area and can influence the other area of life.

The relational articulation: We define it as the exchange of experiences between different areas of life and the interdependence of relationships and experiences lived in the work with those experienced in the off-work.

The temporal articulation: It is the phenomenon of superposition and interference between personal temporalities and professional temporalities. In other words, it is the interference between the time dedicated to work and the one dedicated to the non-work.

\section{Research Hypotheses}

We retain a Central hypothesis $(\mathrm{CH})$ which states that articulation between the spheres of live is a multidimensional construct : it is represented by modes that are at the same time relational, psychological and temporal and it is determined simultaneously by cultural, personal and professional variables.

A postulate and three hypotheses adjacent to $\mathrm{CH}$ are stated to validate the submodels representative of the general determinism of this research:

Postulate: Managers have an identity represented by modes that are at the same time relational, psychological and temporal and it is determined by cultural, personal and professional variables.

H1: the "determinants of the private sphere" significantly influence the articulation between the spheres of life

H2: the "cultural variables" significantly influence the articulation between the spheres of life

H3: the " determinants of the professional sphere " significantly influence the articulation between the spheres of life. Therefore, the following table 2 presents the validation process of these assumptions.

Table 2. Tests and indexes of fit of the model I

\begin{tabular}{ll}
\hline Adjustment indices & Threshold of acceptance \\
\hline$\cdot \chi^{2} \quad(d d l=108)=170,6$ & \\
$\quad p=0,00179$ & $\bullet \mathbf{P}>0,05$ \\
$\cdot \chi^{2} \quad$ normé $(\chi 2 / d d l)=1,62$ & $\bullet<4$ \\
$\cdot$ NFI $=0,91$ & $\bullet>0,9$ \\
$\cdot$ RMSEA $=0,064$ & $\bullet<0,08$ \\
$\cdot$ AGFI $=0,92$ & $\bullet>0,9$
\end{tabular}

Moreover, the coefficients of multiple determinations of the constructs are satisfactory (the R2's greater than 0.5) except for the joint whose variance explained by the spheres of life is $39.2 \%$. This encouraging result shows 
nevertheless, the content of this construct is relatively difficult to delimit and therefore to explain despite the pre-tests. We now discuss in detail the main findings before concluding on the managerial implications.

\section{Findings}

The research model was tested using structural equations which specify the causal relationships between the variables. The variables used are latent, it observed variables having been "corrected" with error measures to increase the fidelity of measures. Regression analyzes were conducted on the latent variables in order to estimate the relationships between the variables of the model. The fit of the model is measured thanks to the ratio studied (chi square). The chi-square referred to the degree of freedom is an index of good fit when it is below a standard variable according to the rigor imposed on the study. The ratio should be close to 1 in order to be considered acceptable. Wheaton \& al. (1977) suggested that researchers calculate a relative chi-square (chi-square / df) for check their model, they propose that a ratio of approximately five or less is "reasonable". As the chi-square of our model rises at 6822.08 and the degree is 1932, the ratio of chi-square equals 3.53, which is acceptable according to the prescribed standards. Although it shows that most of the links proposed by the model are checked, we will focus primarily on the determinants and the direct and respective effects of different articulations between spheres of life.

To assess the relative importance of each modes of articulation between spheres of life, we report the estimated standardized parameters. Subsequently, we will provide the non-standardized parameters that will be used to perform counterfactual experiments.

This model does not show the relationships between the modes of articulation between spheres of life because they are statistically insignificant within our sample.

At first the structural factors are not taken into account. The main results are summarized in Table 3 . The results of the model of estimated structural equations are shown in this model.

Table 3. Validation of Model of structural equations estimated

\begin{tabular}{lll}
\hline $\begin{array}{l}\text { Hypotheses } \\
\text { tested }\end{array}$ & $\begin{array}{l}\text { Results } \\
\text { Expected meaning } \\
\text { relationship }\end{array}$ & $\begin{array}{c}\text { of } \\
\text { the Acceptance of the hypothesis } \\
(\mathbf{a}=\mathbf{0 , 0 5})\end{array}$ \\
\hline $\mathrm{CH}$ & Confirmed & Yes \\
$\mathrm{H} 1$ & Confirmed & Yes \\
$\mathrm{H} 2$ & Confirmed & Yes \\
$\mathrm{H} 3$ & Confirmed & significant with \\
& & \multicolumn{2}{c}{$=0,10$}
\end{tabular}

The multiple articulations between spheres of life studied do not allow us to refute the importance of the variables introduced in our research model and collected from the Word Values Survey (2018).

Moreover, as some determinants Work-family conflicts are under the control of employees or employers, who can, by referring to our results, find possible solutions to work-family balance problems. So, for minimize the "work-family" conflict and maximize satisfaction at work with respect to their lives in general, employees and employers must first and foremost to ensure that they occupy and offer positions where their roles are not very conflictual, not very vague and not very "overloaded". Indeed, the articulation between spheres of life seems much more determined by nature more or less stressful roles at work than by engaging employees in their work and the support offered by leaders and supervisors work-family balance.

However, Tunisian managers have an interest in offer help with work-life balance to their employees because that it turns out to have a direct positive influence on the satisfaction and job performance of these. To our knowledge, this study is the first to analyze and confirm the positive impact of organizational support on work-life balance on performance at the work of the employees.

In addition, our study reveals to employees that to better minimize their conflict. 
Moreover, our results show that it is more important to live with a spouse "supporting" that to become more involved in the family to reduce the conflict "family / work". According to the terms of the border theory (see Campbell 2000), this result confirms the importance of the spouse as guardian of the boundary between family and professional. This result is also consistent with that of Capelli, Constantine and Chadwick (2000) according to which the choice of a spouse that values the family is an important determinant of employee career success. In our opinion, future studies should explore more and more accurately the importance and nature of attitudes and the behavior of the spouse on the skills of the employees to manage their work-family balance. In addition, it would be important to see if spousal support is more important for women than for men to balance work and family lives.

This study has certain limitations. The results depend on the relevance of the proposed model and the quality of measurement scales which in several cases have been developed by the authors. However, many of the scales selected are translated or adapted from measures used by other authors. In addition, social desirability and length of the questionnaires may have influenced the responses expressed by the respondents. In addition, the use of an intermediary to transmit and retrieve the questionnaires has disadvantaged the participation of employees. In addition, the results can be

specific to our sample composed exclusively of unionized employees and for the most part, women (75\%). Also, it would be interesting that future studies test the proposed model or similar models with other employee populations.

\section{Conclusion}

The purpose of this paper was to propose a model based on the structural equations method to simultaneously test the articulations between spheres of life with Tunisian managers. However, the model obtained leads to a certain hierarchy of the effects of the spheres of life.

In addition, the results should be interpreted taking into account a number of limitations attached to this first proposed model, including the choice of variables studied from the Word Values Survey (2018).

Also, to increase the external validity of this measurement model and extend the search to other organizational contexts, other empirical studies are desirable. If the variables used for the representation of the articulation between the spheres of life still seem to improve, they constitute a sketch towards a measure or estimate of this concept by nature encompassing. Indeed, if the most commonly used means is, for ease, to dissociate the domains of life, an integrative approach seems preferable to the juxtaposition of spheres of life to appreciate the global nature of articulation. In this sense, the proposed variables can create learning dynamic and expand options for more in-depth future research pathways.

\section{References}

Amado G., Bouilloud J-P., Lhuillet D. \& Ulmann A.L. (2017). La créativité au travail. Paris, France, Editions Erès.

Bouffartigue, P., Bocchino, M. (1998). Travailler sans compter son temps? Les cadres et le temps de travail . Travail et Emploi, 74, 37-50.

Brais, N. (2000). La dimension géographique de l'articulation vie professionnelle/vie familiale : stratégies spatiales familiales dans la Région de Québec. Thèse de Doctorat en philosophie, Université Laval, Québec.

Brousseau E. \& Rallet A. (1997). Le rôle des tech - nologies de l'information et de la communication dans le changement organisationnel, in B. Guilhon et al (eds), Economie de la connaissance et dynamique des organisations, Paris, France, L'Harmattan.

Carré D. \& Vétois J. (2016). Contrôle social et techniques numériques. TIC \& Société, 10(1), 1-13. https://doi.org/10.4000/ticetsociete.1973

Cazals F. (2015). Stratégies digitales. La méthode des 6C, Paris, Deboeck Supérieur.

Chakor T. (2014). Les consultants dans la préven - tion des risques psychosociaux au travail : proposition d'une typologie de pratiques, @GRH, 1(10), 37-58. https://doi.org/10.3917/grh.141.0037

Capelli, C. \& Chadwick, P. (2000). It Pays to Value Family: Work and Family Tradeoffs Reconsidered. Journal of Economy and Society. https://doi.org/10.2139/ssrn.222228

Champy-Remoussenard P. (2015). Les transformations des relations entre travail, éducation, et formation dans l'organisation sociale contemporaine : questions posées par trois dispositifs analyseurs. Revue française de pédagogie, (190), 15-28. https://doi.org/10.4000/rfp.4675 
Colle R., Christin J. (2008). Couples à double carrière et articulation vie privée - vie professionnelle : Le mariage de la carpe et du lapin ? 19ème Congrès de l'AGRH, Dakar (Sénégal).

Chrétien, L. (2005). La conciliation travail-famille dans les MRC de Bellechasse, Lévis et Lotbinière. Rapport de recherche. Québec : CRAD, INRS-Urbanisation et CAMF.

Dorn D. (2017). La montée en puissance des machines : comment l'ordinateur a changé le travail. Revue française des affaires sociales, 1, 35-63.

Desmarais C. (2006). Encadrer, une promenade de santé ? Management \& Avenir, 2006/2 (n 8), 159 à 177. https://doi.org/10.3917/mav.008.0159

Del Río Carral, M., Fasseur F., Santiago-Delefosse, M. (2009). Porosité » entre travail et vie privée, conflits et aménagements : une étude comparative. Pratiques psychologiques, 15, 155-171. https://doi.org/10.1016/j.prps.2008.09.002

Fayolle A. (2017). Entrepreneuriat, Paris, Editions Dunod.

Frimat P. (2010). Le travail ...c'est la santé : la santé c'est le travail... une pratique en questions. Perspectives interdisciplinaires sur le travail et la santé, (2), 2-9. https://doi.org/10.4000/pistes.1626

Frimousse S. \& Peretti J-M. (2016). Regards croisés, Question(s) de Management, (13), 8. https://doi.org/10.3917/qdm.161.0105

Galerand E. \& Kergoat D. (2014), Les apports de la sociologie du genre à la critique du travail, La nouvelle revue du travail, (4,) 2-14.

Félio, C., (2014). Pratiques communicationnelles des cadres : usage intensif des TIC et enjeux psychosociaux. Thèse de doctorat en Sciences de l'information et de la Communication, Université Michel de Montaigne, Bordeaux.

GALLUP, (2013). State of Global Workplace: employee engagement insights for business leaders worldwide.

Guilbert 1. (2006). L'équilibre des domaines de vie des cadres. Le Journal des psychologues, 2006/7 $\left(n^{\circ} 240\right)$, pages 67 à 70. https://doi.org/10.3917/jdp.240.0067

Hanique F. (2014). Le Sens du travail. Chronique de la modernisation au guichet, Toulouse, Érès. Jacquet D. \& Leclercq G. (2016), Ubérisation : Un ennemi qui vous veut du bien ?, Malakoff, Editions Dunod.

Jarvier C. (2013). A Critical Review of Construct Indicators and Measurement Model Specification in Marketing and Consumer Research.

Kline, R.B. (2011). Principles and Practice of Structural Equation Modeling. Guilford Press, New York.

Khanchel, H. (2016). Pour une meilleure comprehension de l'articulation entre le temps de travail et le temps hors travail chez les cadres tunisiens. Thèse de Doctorat en sciences de gestion, Université Manouba, Tunisie.

Laquelle, S. (2013). Pour une meilleure articulation entre vie professionnelle et vie familiale. Ministère de la réforme de l'Etat, le la décentralisation et de la fonction publique, République Française, Janvier 2013.

Lejealle, C. (2009). Le mobile professionnel : un outil de conciliation ou de confinement dans la charge du care pour les femmes cadres ?, Temporalités, mis en ligne le 30 septembre 2009. https://doi.org/10.4000/temporalites.1010

Lefèvre, E., Bourgouin, C., \& Chatauret, A. (2000). Agir sur... le temps de travail des cadres. Paris : Éditions Liaisons.

Lenoir and all. (2014). Equilibre des sphères de vie et prévention des risques psychosociaux. Le cas des exploitants agricoles. RIMHE. Revue Interdisciplinaire Management, Homme \& Entreprise, 2014/3 (n 12), pages 45 à 61. https://doi.org/10.3917/rimhe.012.0045

Mongrand, J.-P. (1999). Les cadres et les 35 heures: mode d'emploi. Paris : Les Éditions d'Organisation.

Ollier-Malaterre, A. (2008). Comment les employeurs appréhendent-ils la vie hors travail de leurs salariés ? Une comparaison entre le modèle français et le modèle anglo-américain. Recherches et Prévisions, 92, 47-60. https://doi.org/10.3406/caf.2008.2369

Pochic S. (2000). Comment retrouver sa place ?: Chômage et vie familiale de cadres masculins. Travail, genre et sociétés, 2000/1 ( $\left.\mathrm{N}^{\circ} 3\right), 87$ à 108. https://doi.org/10.3917/tgs.003.0087

Roquejoffre A. (2017). La technologie face à la dépendance, espoirs et impasses, Empan, (91), 22-29. https://doi.org/10.3917/empa.091.0022 
Silvera R., Buseyne N., Donlevy-Gomes V. (2004). Articuler vie professionnelle et vie personnelle - Les expérimentations des projets Equal français 2001-2004. Cahier Racine. 38292.

Silvera, R., (2002). Articuler vie familiale et vie professionnelle en Europe : un enjeu pour l'égalité. Paris, $L a$ Documentation française.

St-Onge, S., Renaud, S., Guérin, G. \& Caussignac , E. (2002). Vérification d'un modèle structurel à l'égard du conflit travail-famille, Relations industrielles. https://doi.org/10.7202/006887ar

Teboul B., Picard T. \& Wargnier X. (2015). Ubérisation = Economie déchirée ?, Bluffy, Editions Kawa. Tran S., (2014), Quelle contribution des technologies collaboratives à la configuration des organisations. Système d'information et management, 19(12), 75-111. https://doi.org/10.3917/sim.142.0075

Tanquerel, S et Barth, I. (2012). Gérer les frontières vie privée/professionnelle : quels enjeux pour le manager ? IIIèmes Etats Généraux du Management, Les nouvelles frontières du management, Strasbourg, 11-12 octobre.

Tremblay, D.-G. (2012). Temps professionnel et temps personnel, aux frontières du management : une comparaison France - Québec, Communication aux 3e États généraux du management, Strasbourg, les 11-12 octobre 2012.

Tessier, M. (2009). étude de la conciliation travail-vie personnelle de femmes en situation récurrente d'emplois atypiques. Mémoire présenté à la Faculté des études supérieures de l'Université Laval, Québec.

Tremblay, D-G., Génin, E. (2008). Permeability between work and non-work: the case of IT self-employed workers. Canadian Journal of Communication, 33(4), 701-720. https://doi.org/10.22230/cjc.2008v33n4a1994

Westerman G., Bonnett D. \& McAffee A. (2014). Gagner avec le digital, Paris, Editions Diatein.

Wheaton, B., Muthen, B., Alwin, D., F., \& Summers, G. (1977). Assessing Reliability and Stability in Panel Models. Sociological Methodology, 8(1), 84-136. https://doi.org/10.2307/270754

World Values Survey. (2018). Official site : www.worldvaluessurvey.org 